\title{
Penerapan Augmented Reality Technology Pada Museum Sangiran Dan Analisis Investasi Teknologi Informasi Menggunakan Metode Information Economics
}

\author{
Fendy Prasetyo Nugroho ${ }^{1}$, Kusrini2 ${ }^{2}$, Emha Taufiq Luthfi ${ }^{3}$ \\ 1,23. Program Pascasarjana Magister Teknik Informatika, Universitas AMIKOM Yogyakarta, Indonesia \\ E-mail:fendy.nugroho@students.amikom.ac.id1',kusrini@amikom.ac.id², emhataufiqluthfi@amikom.ac.id³
}

\begin{tabular}{|c|c|}
\hline Info Artikel & Abstrak \\
\hline $\begin{array}{l}\text { Kata Kunci: } \\
\text { augmented reality technology, } \\
\text { information economics, } \\
\text { museum sangiran, investasi }\end{array}$ & $\begin{array}{l}\text { Museum Sangiran merupakan sebuah situs purbakala berlokasi di Kabupaten Sragen } \\
\text { yang mempunyai banyak sejarah kehidupan dan merupakan situs manusia purba } \\
\text { terlengkap di Asia. Sangiran termasuk dalam salah satu situs terpenting untuk } \\
\text { penelitian dan perkembangan macam-macam bidang ilmu pengetahuan terutama } \\
\text { untuk kegiatan perkembangan bidang teknologi informasi serta pengembangan bidang } \\
\text { pariwisata peninakatan kemampuan ekonomi kreatif masvarakat dan investasi. }\end{array}$ \\
\hline $\begin{array}{l}\text { Keywords: } \\
\text { augmented reality technology, } \\
\text { information economics, } \\
\text { sangiran museum, } \\
\text { investation }\end{array}$ & $\begin{array}{l}\text { Dengan berkembangnya teknologi informasi dan Augmented Reality Technology } \\
\text { (ART) sebagai media pembelajaran dan media promosi, Museum Sangiran saat ini juga } \\
\text { telah memanfaatkan teknologi informasi dan menerapkan ART sebagai media } \\
\text { pembelajaran, media informasi dan media promosi untuk meningkatkan investasi } \\
\text { daerah. Dengan pemanfaatan teknologi informasi khususnya ART sebagai media } \\
\text { promosi tentu saja memerlukan biaya investasi yang cukup besar, sehingga pengelola }\end{array}$ \\
\hline Tanggal Artikel & Museum Sangiran harus jeli untuk dapat melihat manfaat apa yang akan didapatkan \\
\hline Dikirim : 02 Agustus 2019 & apabila menerapkan teknologi informasi sebagai media promosi. Penelitian ini \\
\hline : 20 Agustus 2019 & dilakukan untuk menganalisa dan mengukur kelayakan investasi teknologi informasi \\
\hline Diterima : 21 Agustus 2019 & $\begin{array}{l}\text { pada proyek pemanfaatan ART berdasarkan metode information economics sehingga } \\
\text { dapat mengetahui tentang biaya yang dikeluarkan apakah sudah sebanding dengan } \\
\text { manfaat yang diperoleh oleh pengelolaMuseum Sangiran dan dapat dijadikan referensi } \\
\text { dalam menyusun pagu anggaran dan rencana strategis dalam pengembangan } \\
\text { museum Sangiran. Hasil yang didapat bahwa pada tingkat faktor bisnis domain dan } \\
\text { faktor teknologi domain pada Museum Sangiran didapatkan hasil dengan predikat } \\
\text { cukup. Hal tersebut memberikan tanda bahwa nilai investasi terhadap penerapan } \\
\text { teknologi informasi ART pada Museum Sangiran memiliki nilai resiko yang cukup kecil } \\
\text { sehingga mudah dikembangkan. }\end{array}$ \\
\hline
\end{tabular}

Abstarct

Sangiran Museum is an ancient site located in Sragen regency where has a lot of life history and is the most complete ancient human site in Asia. Sangiran is one of the most important sites for research and development in various fields of science. Such as development activities in the field of information technology and the development of the field of tourism and increasing the ability of the people's creative economy and investment. The Sangiran Museum now also utilizes information technology and applies ART as a learning media, information media and promotional media to increase regional investment. With the use of information technology, especially ART as a promotional medium, of course, requires a substantial investment cost, so that the manager of the Sangiran Museum can perceive what benefits will be obtained if information technology as a promotional medium is applied. This research was conducted to analyze and measure the feasibility of information technology investment in ART utilization projects based on the information economics method so that they can find out about the costs incurred whether it is comparable with the benefits obtained by the Sangiran Museum manager and can be used as a reference in preparing the budget ceiling and strategic plans in development Sangiran museum. The results obtained that at the level of business domain factors and domain technology factors at the Sangiran Museum, the results obtained with a predicate are sufficient. This gives a sign that the value of investment in the application of ART 
information technology at the Sangiran Museum has a risk value that is small enough to be easily developed.

\section{PENDAHULUAN}

Beralihnya perkembangan teknologi dari dunia analog menuju digital tentu saja akan menambah variasi dalam sebuah visualisasi pada sebuah karya teknologi informasi. Pengembangan multimedia di era ini juga semakin beragam dan akan terus berkembang dengan cepat. Museum Sangiran merupakan sebuah situs purbakala yang berada di Kabupaten Sragen yang dimana adalah sebuah situs mempunyai banyak sejarah kehidupan dan merupakan situs manusia purba yang terlengkap di Asia. Selain itu, Sangiran adalah situs terpenting yang tersedia saat ini untuk melakukan penelitian dan perkembangan berbagai macam bidang ilmu pengetahuan terutama untuk penelitian dan perkembangan pengetahuan di bidang antropologi, arkeologi, biologi, paleoantropologi, geologi, teknologi serta pengembangan bidang pariwisata dan peningkatan kemampuan ekonomi kreatif masyarakat dan investasi. Keberadaan Situs Sangiran sangat bermanfaat untuk mempelajari kehidupan manusia prasejarah karena situs ini dilengkapi dengan fosil manusia purba, hasil-hasil budaya manusia purba, fosil flora dan fauna purba beserta gambaran stratigrafinya. [1] Pelestarian dan perawatan situs purbakala yang dilakukan di Museum Sangiran merupakan salah satu cara agar sejarah di Sangiran dapat diketahui dan dipelajari oleh masyarakat luas. Aplikasi teknologi informasi akan membuat pengguna menjadi lebih mudah untuk memahami serta membuat penyampaian informasi lebih interaktif.

Augmented Reality Technology (ART) merupakan teknologi yang dapat menggabungkan benda-benda nyata dan maya di lingkungan nyata, berjalan secara interaktif dalam waktu nyata dan terdapat integrasi antar benda sehingga teknologi tersebut dapat digunakan sebagai media informasi, media pembelajaran dan media promosi yang efektif dan efisien. Penelitian yang dilakukan oleh IImawan telah mengembangkan ART yang digunakan sebagai media pembelajaran. Melalui ART, guru dapat membuat media pembelajaran yang menyenangkan, interaktif, dan mudah digunakan. ART juga dapat menggantikan modul pembelajaran yang belum ada di sekolah dalam bentuk virtual atau maya. Siswa di sekolah tetap dapat melihat dan menggunakan modul seperti modul aslinya, namun dalam bentuk virtual. [2]

Menurut survey [3], 51\% perusahaan tidak pernah melakukan evaluasi investasi Sistem Informasi (SI) / Teknologi Informasi (TI), bahkan 68\% perusahaan tidak membandingkan manfaat yang diperoleh dengan nilai investasi yang telah dikeluarkan. Berdasarkan hal tersebut, untuk mengetahui hasil dan manfaat dari investasi SI/TI dibutuhkan sebuah perencanaan proyek SI/TI yang maksimal. Beberapa kerangka kerja yang dapat digunakan untuk memaksimalkan perencanaan proyek SI/TI adalah dengan menghitung nilai atau kontribusi dari investasi yaitu information economics (IE), Total Economic Impact dan VAL IT Framework. Analisis biaya dan manfaat adalah instrument untuk menilai apakah suatu proyek layak untuk diimplementasikan atau tidak. Proyek yang saat ini sedang dipertimbangkan pada penelitian tersebut adalah sistem informasi akademik dan sistem koneksi internet. Kedua proyek investasi tersebut akan dinilai cost-benefit-nya. Hasil penilaian berupa rekomendasi kepada pihak yang berkepentingan mengenai proyek mana yang sebaiknya dibangun. [4]

Kerangka kerja IE dipilih untuk dapat menghubungkan kinerja dari suatu bisnis dengan perkembangan teknologi informasi. Metode IE tentunya dapat membantu menganalisis manfaat dari biaya investasi proyek penggunaan teknologi informasi sebagai media promosi. Berdasarkan penelitian-penelitian terdahulu juga diketahui bahwa penggunaan metode IE dapat membantu untuk menentukan nilai sebuah investasi yang diharapkan dapat mendatangkan nilai keuntungan yang lebih besar dari sebelumnya. Selain itu juga perlu memperhitungkan nilai-nilai ekonomis yang akan diperoleh dari investasi teknologi informasi pada tahun yang sedang berjalan maupun tahun-tahun yang akan datang. Atas dasar itulah penelitian ini dilakukan untuk menganalisa dan mengukur kelayakan investasi teknologi informasi pada proyek pemanfaatan Augmented Reality Technology berdasarkan metode information economics sehingga sehingga dapat mengetahui tentang biaya yang dikeluarkan apakah sudah sebanding dengan manfaat yang diperoleh oleh pengelola Museum Sangiran.

\section{METODE PENELITIAN}

Metode penelitian yang digunakan adalah sebagai berikut:

\subsection{Metode Studi Kepustakaan}

Melakukan pengumpulan dasar-dasar sebagai landasan teori dan sumber referensi melalui internet untuk mencari penelitian-penelitian sebelumnya melalui publikasi ilmiah dan paparan seminar, membaca buku referensi yang terkait dengan permasalahan yang dibahas mengenai Museum Sangiran, Augmented Reality Technology dan Information Economics serta teori sebagai bahan pendukung lainnya yang menjadi acuan dalam penelitian yang dilakukan ini.

\subsection{Metode Survei Lapangan}

Memperoleh data dan informasi tentang Museum Sangiran dengan cara:

a. Melakukan wawancara dengan pihak terkait tentang penerapan aplikasi teknologi informasi ART. 
b. Melakukan kegiatan observasi tentang bagaimana implementasi teknologi informasi yang dilakukan oleh pengelola Museum Sangiran dan implementasi investasi teknologi informasi pada aplikasi tersebut.

c. Membuat daftar dan menyusun pertanyaan yang ditunjukkan kepada pihak pengelola Museum Sangiran.

d. Melakukan studi dokumentasi yang dapat dilakukan langsung di lapangan dan pinjaman dari pengelola museum.

\subsection{Metode Analisis/Evaluasi}

Melakukan analisis lebih lanjut tentang penerapan Augmented Reality Technologysebagai media promosi pada Museum Sangiran dengan metode studi kepustakaan dan studi lapangan serta melakukan analisis terhadap hasil penelitian yang diperoleh dengan menggunakan langkah dan metode analisis information economics yaitu suatu metode yang secara ilmiah dikembangkan dari pengukuran konvensional akuntansi untuk mengklasifikasi, mengukur, dan mengoptimalkan investasi tekonologi informasi dengan pendekatan pengukuran nyata (tangible) dan pengukuran tidak nyata (intangible).

\subsection{Tahapan Penelitian}

Adapun tahap pemecahan masalah akan mengikuti kerangka kerja Information Economics. Secara lengkap, langkahlangkah pemecahan masalah adalah seperti pada Gambar 1.

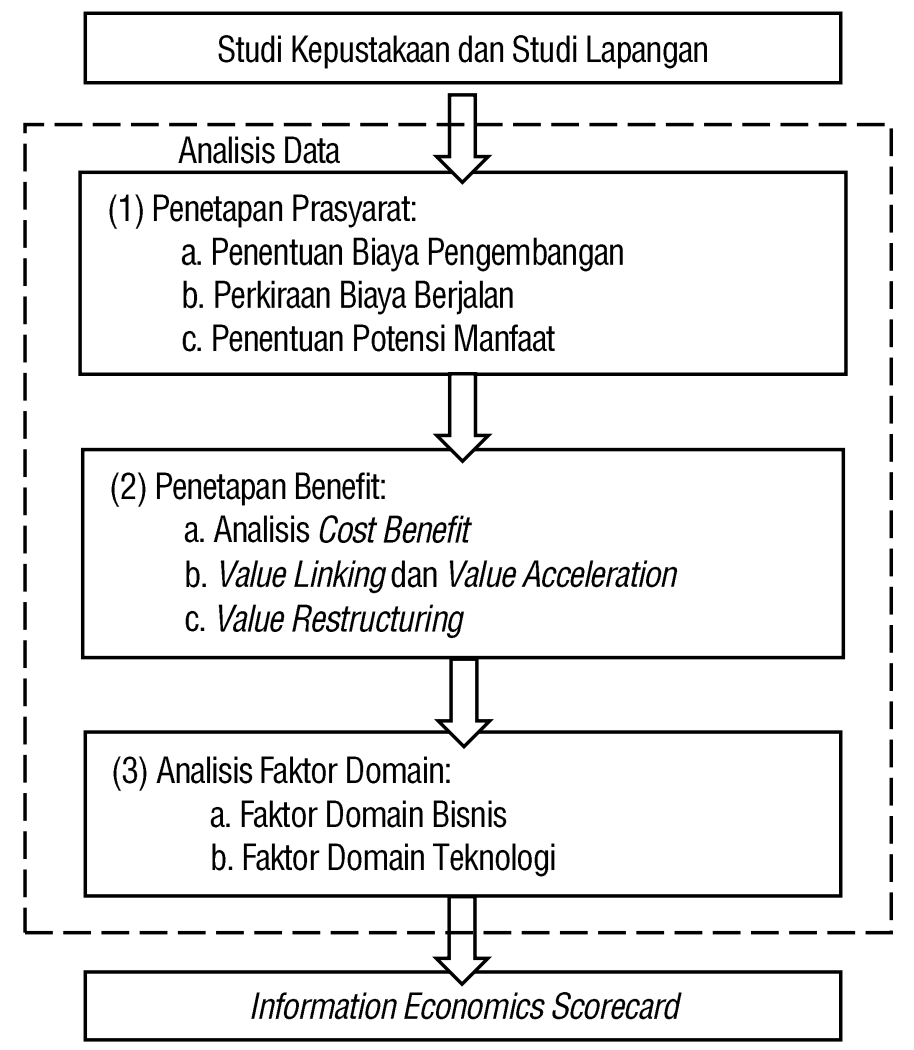

Gambar 1. Tahapan Penelitian

\section{HASIL DAN PEMBAHASAN}

\subsection{Penerapan Augmented Reality Technology}

Pada penerapan Teknologi Informasi Augmented Reality Technology pada Museum Sangiran sudah sesuai dengan Rencana Strategis Jangka Panjang dari Pengelola Museum Sangiran yaitu Balai Pelestarian Situs Manusia Purba Sangiran (BPSMPS) dan Pemerintah Daerah Kabupaten Sragen. Aplikasi ART diterapkan pada Museum Sangiran untuk membantu pengelola dalam melakukan promosi tentang Sangiran yang diterapkan sebagai media pembelajaran, media informasi dan media promosi. Dengan memanfaatkan ART yang dibuat secara interaktif dan dikemas dalam sebuah aplikasi yang berisi tentang informasi benda-benda purbakala koleksi Museum Sangiran akan dapat lebih mempermudah dalam membawanya keliling Indonesia untuk dapat dilihat dan dipelajari masyarakat atau wisatawan tanpa harus menyentuh fosil aslinya.

Salah satu produk ART yang akan dilakukan kajian investasi teknologi informasi adalah ART berbasis Android tentang video promosi Museum Sangiran yang sudah pernah dibuat dengan memanfaatkan merchandise sebagai media untuk menjalankan aplikasi Android tersebut. Dengan diciptakannya teknologi informasi berbasis Android 
tersebut program yang dibuat dapat menampilkan informasi untuk mempromosikan tempat wisata Museum Sangiran yang berada di Kabupaten Sragen. Selain itu juga dapat meningkatkan pengetahuan tentang teknologi serta program ini juga menumbuhkan kemampuan berwirausaha dalam rangka untuk meningkatkan perekonomian masyarakat karena media yang digunakan untuk menjalankan aplikasi berupa merchandise yang meliputi kaos, buku panduan, gantungan kunci dan tas.

Untuk implementasi atau cara menjalankan aplikasi ART berbasis Android dapat dilihat pada ilustrasi model perancangan aplikasi seperti Gambar 2 dan proses perancangan navigasi dari penerapan aplikasi ART dapat dilihat pada Gambar 3.

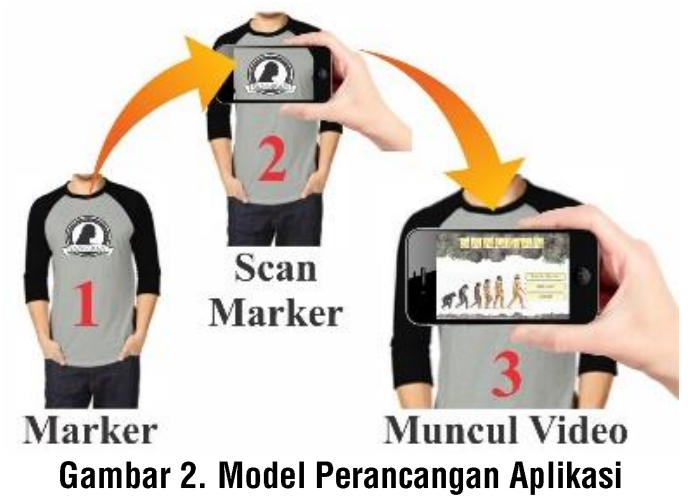

\subsection{Penerapan Information Economics}

\subsubsection{Penetapan Benefit}

\section{a. Analisis Cost Benefit}

Costatau biayaadalah sebuah nilai yang harus dikeluarkan untuk dapat memperoleh suatu produk, sedangkan manfaat (benefit) merupakan keuntungan langsung ataupun tidak langsung yang didapat oleh suatu institusi. Manfaat lebih berupa pada arah untuk melakukan penghematan biaya, pengurangan biaya, memperoleh keuntungan, dalam peningkatan efektifitas atau produktifitas karyawan. [4]

Terdapat 2 jenis biaya yaitu: [4]

1. Biaya pembangunan sistem

Menentukan biaya pengembangan investasi sistem dan teknologi informasi yang mengacu pada IFS (Industrial and Financial System). Nantinya akan didapatkan total biaya pengambangan sistem dan teknologi informasi pada Museum Sangiran.

2. Biaya pemeliharaan atau biaya operasional

Setelah biaya pengembangan sistem dan teknologi informasi tersebut terekap, kemudian menentukan biaya proses berjalan yang dikeluarkan selama lima tahun. Hasil yang didapat adalah perhitungan hasil perkiraan jumlah biaya berjalan selama pengembangan dalam lima tahun yang terdapat total masing-masing tahun dan kebutuhan yang tertera serta total keseluruhan selama lima tahun berialan.

Selain itu juga terdapat 3 jenis manfaat, yaitu: [4]

1. Tangible benefityaitu sebuah manfaat yang nilainya dapat diukur atau langsung tampak pada nilai perhitungan

2. Quasi-Tangible benefit sebuah manfaat yang berfungsi untuk meningkatkan efisiensi pada organisasi atau pengelola

3. Intangible benefitsebuah manfaat untuk melakukan peningkatan efektifitas pada organisasi atau pengelola

Hasil biaya pengembangan sistem dan teknologi informasi di tambah dengan biaya proses berjalan yang diinvestasikan pada Museum Sangiran tentunya akan menimbulkan efek manfaat. Manfaat tersebut dapat berbentuk tangible maupun yang bersifat intangible. Sistem dan teknologi informasi di Museum Sangiran menghasilkan potensi manfaat seperti terlihat pada Tabel 1.

Tabel 1. Potensi Manfaat

\begin{tabular}{|c|c|c|c|c|c|}
\hline \multirow{2}{*}{ No. } & \multirow{2}{*}{ Potensi Manfaat/Benefit } & \multicolumn{3}{|c|}{ Klasifikasi } & \multirow{2}{*}{ Metode Pengukuran } \\
\hline & & Aspek & Domain & Value & \\
\hline 1 & $\begin{array}{l}\checkmark \text { Pengurangan penggunaan } \\
\text { barang habis pakai } \\
\checkmark \quad \text { Pengurangan jumlah pegawai }\end{array}$ & Reduction Cost & Bisnis & Finansial & $\begin{array}{c}\text { Cost Benefit Analyst } \\
\text { (CBA) }\end{array}$ \\
\hline 2 & $\checkmark$ Peningkatan jumlah pengunjung & Increasing Revenue & Bisnis & Finansial & Cost Benefit Analyst \\
\hline
\end{tabular}




$\begin{array}{ccccccc}3 & \checkmark & \text { Kecepatan penggunaan aplikasi } & \text { Accelerating Cash in } & \text { Teknologi } & \text { Non Finansial } & \begin{array}{c}\text { Information } \\ \text { Economics (IE) }\end{array} \\ 4 & \checkmark & \text { Kecepatan informasi } & \text { Increasing Quality } & \text { Teknologi } & \text { Non Finansial } & \text { IE, Value Acceleration } \\ 5 & \checkmark & \text { Peningkatan produktifitas kerja } & \text { Increasing } & \text { Bisnis } & \text { Non Finansial } & \text { Information } \\ & \text { pegawai } & \text { Productivity } & & & \text { Economics (IE) } \\ & \checkmark \text { Peningkatan kualitas informasi } & & & \\ & \text { dan penyajiannya } & & & \end{array}$

\section{b. Value Linking dan Value Acceleration}

Value Linking merupakan suatu nilai yang dapat digunakan untuk melakukan evaluasi sebagai dampak dari sebuah peningkatan kinerja suatu fungsi terhadap fungsi-fungsi lain yang terpisah. Value Linking juga menunjukkan ripple effect yang dapat terjadi akibat adanya perubahan dalam fungsi pengelolaan atau proses kerja.

Manfaat-manfaat yang diperoleh dari unit funsional lain dalam kegiatan operasional ini adalah dapat mengurangi biaya akomodasi dan dapat melakukan penghematan pada anggaran keuangan. Value Accelerationmerupakan suatu cara atau teknik yang dapat dipakai untuk melakukan sebuah evaluasi secara finansial untuk manfaat pengurangan atau dengan percepatan waktu karena terdapat sebuah hubungan sebab akibat antara dua fungsi tersebut. Teknik ini dinilaikan pada suatu domain bisnis dan dijumlahkan ke dalam sebuah lembar kerja dampak ekonomis. Hal ini terjadi pada pendapatan bunga yang mengalami peningkatan setiap tahunnya.

c. Value Restructuring

Value Restructuring adalah nilai yang terkait dengan restrukturisasi fungsi-fungsi suatu pekerjaan dari sebuah pengelolaan manajemen. Value Restructuring dipakai untuk melakukan pengukuran tentang sebuah peningkatan nilai produktifitas yang sudah dihasilkan oleh adanya sebuah proyek teknologi informasi pada suatu manajemen pengelolaan.

Setelah penerapan ART pada Museum Sangiran maka dapat dibuat asumsi atau perkiraan jumlah perhitungan terhadap dampak ekonomis pada nilai investasi teknologi informasi dengan hasil nilai Return On Invesment (ROI) sederhana seperti pada Tabel 2.

Tabel 2. Lembar Kerja Dampak Ekonomis (Value Linking) [5]

\section{Lembar Dampak Ekonomis (Dalam Ribuan Rp)}

A. Biaya Investasi Penggantian Perangkat Keras dan Perangkat Lunak

B. Arus Kas: Periode 5 tahun atas penerapan proyek ART

$$
\begin{array}{cccc}
\text { Tahun } & \mathrm{Ke}-1 \quad \mathrm{Ke}-2 \underset{\text { (Dalam Ribuan Rp) }}{\mathrm{Ke}-4} \mathrm{Ke}-5 \\
& & &
\end{array}
$$

$\begin{array}{lrrrrr}\text { Manfaat Ekonomis } & 9.500 & 9.500 & 9.500 & 9.500 & 9.500 \\ \text { Pengurangan Biaya } & 23.000 & 23.000 & 23.000 & 23.000 & 23.000 \\ \text { Perolehan } & 32.500 & 32.500 & 32.500 & 32.500 & 32.500 \\ \text { (-) Biaya Operasional } & 750 & 1.250 & 1.250 & 1.250 & 1.250 \\ \text { Arus Kas Netto } & 31.750 & 31.750 & 31.750 & 31.750 & 31.750\end{array}$

C. ROI Sedehana $(156.750 .000 / 5 / 22.818 .000) * 100 \%=138 \%$

D. Skor, Dampak Ekonomis

\begin{tabular}{rrrr} 
Skor & \multicolumn{2}{r}{ ROI Sederhana } \\
0 & & $<=$ & 0 \\
1 & $1 \%$ & s/d & $299 \%$
\end{tabular}

Dengan cara yang sama dengan value linking, value acceleration memberikan manfaat Rp. 82.900 .000 (72\%) dan value restructuring Rp. 233.250 .000 (204\%). Jadi total keseluruhan manfaat adalah Rp. $156.750 .000+R p$. $82.900 .000+$ Rp. $233.250 .000=$ Rp. $472.900 .000(414.5 \%)$.

Hasil analisis tentang manfaat tangible dengan menggunakan cost benefit tradisional dapat diperoleh sebuah manfaat ekonomi netto, menghasilkan sebuah nilai ROI 1 dan skor dampak ekonomis yang pertama. Kemudian 
penjumlahan nilai dari Value Linking dan Value Acceleration yang dapat dikerjakan bersama-sama dengan analisis manfaat intangible yang meliputi faktor domain bisnis dan factor domain teknologi pada model bisnis institusi.

Nilai dari sebuahvalue restructuring harus dapat berkaitan dengan faktor-faktor domain. Kemudian hasilnya akan dijumlahkan dengan nilai ROI 2 untuk menghasilkan nilai ROI 3 dan skor dampak ekonomis yang ketiga. Penjumlahan nilai pada Innovation Valuationyang berkaitan dengan faktor domain yang hasilnya dijumlahkan dengan nilai dari ROI 3 untuk mendapatkan hasil nilai ROI 4 dan dampak ekonomis yang keempat. Langkah terakhir yang dianalisa adalah skor dampak ekonomis dan semua faktor pada domain bisnis dan domain teknologi dimasukkan dan dianalisa untuk mendapatkan nilai akhir menggunakan Information Economics Scorecard.

\subsubsection{Analisis Faktor Domain}

a. Faktor Domain Bisnis

Faktor domain bisnis melakukan pengukuran pada pengaruh penerapan sebuah teknologi informasi pada kemampuan bisnis dari sebuah manajemen pengelolaan. Teknologi informasi dapat melakukan perubahan budaya kerja dan dapat melakukan peningkatan sebuah keunggulan yang dapat bersaing antar manajemen pengelola sebuah institusi dan bahkan bisa menjadi sebuah pelopor untuk manajemen pengelolaan di tempat lain atau pada sebuah institusi lain.

Di dalam faktor domain bisnis terdapat lima faktor yang dapat mempengaruhi terhadap teknologi informasi selain perhitungan ROI sederhana yang harus dilakukan evaluasi supaya pembobotan menjadi lebih baik dan skor dari sebuah proyek menjadi lebih realistis. Kelima faktor tersebut yaitu:

1. Faktor Strategic Match (SM)

Nilai dari factor strategic match bergantung pada sebuah keadaan dimana proyek yang diusulkan berhubungan dengan sebuah tujuan strategis yang sebelumnya sudah ditentukan.

2. Faktor Competitive Advantage (CA)

Melakukan evaluasi tentang adanya sebuah pertukaran data antar menajemen pengelola dengan para pemasok, distributor atau unit kerja lain untuk dapat meningkatkan tingkat kompetitif pada sebuah manajemen pengelolaan atau institusi.

3. Faktor Management Information Support (MI)

Nilai dari sebuah faktor yang dapat menentukan sebuah proyek yang dibangun dapat memberi dukungan manajemen terhadap manajer atau manajemen lainnya ataukah tidak.

4. Faktor Competitive Response (CR)

Nilai pada faktor ini digunakan untuk dapat mengukur sebuah kegagalan proyek yang dikerjakan menyebabkan daya kompetitif perusahaan rusak ataukah tidak.

5. Faktor Project or Organizational Risk (OR)

Tahap pengukuran pada faktor $\mathrm{OR}$ terpusat pada pengguna atau sebuah domain bisnis manajemen pengelola yang bukan merupakan sebuah manajemen pengelolaan teknis. Komponen dari sebuah kapasitas manajemen pengelolaan meliputi dukungan dari perubahan suatu manajemen, penilaian yang realistis terhadap tugas dalam rangka menyelesaikan sebuah proyek melalui sebuah bisnis proses dan fungsi dari teknologi informasi tersebut.

\section{b. Faktor Domain Teknologi}

Pada faktor domain teknologi terdapat banyak nilai dan resiko penting yang tidak tercermin pada kualifikasi keuangan seperti kalkulasi sederhana pada perhitungan nilai ROI. Beberapa nilai dan resiko yang ada memiliki sifat yang unik pada domain teknologi, arsitektur strategis pada sistem informasi, ketidakpastian definisional, ketidakpastian teknik dan resiko infrastruktur informasi. Faktor ini memberikan keterangan tentang strategi teknologi informasi yang mana alternatif investasi dapat dilakukan peninjauan terhadap teknologi informasi tersebut.

a. Strategic IS Architecture (SA)

Nilai yang berfungsi untuk dapat menentukan arsitektur sistem informasi yang dibangun sudah sesuai dengan blueprintmanajemen pengelolaan. Proyek yang mempunyai keterkaitan dengan blueprintmemiliki nilai lebih tinggi.

b. Definitional Uncertainty (DU)

Nilai yang dapat menunjukkan sebuah keadaan yang mana pada kebutuhan tersebut dan atau spesifikasi yang diberikan telah jelas dari awal. Jika suatu kebutuhan tidak dapat diketahui maka skor akan semakin tinggi.

c. Technical Uncertainty (TU)

Nilai yang dapat menunjukkan empat faktor yang dinilai yaitu: keterampilan yang dibutuhkan, ketergantungan dengan sebuah perangkat keras (hardware), perangkat lunak (software) dan perangkat lunak aplikasi.

d. IS Infrastructure Risk (IR) 
Nilai yang dapat menunjukkan sebuah nilai investasi pada non proyek yang penting untuk dapat mengakomodasikan proyek yang sudah ada. Nilai ini merupakan suatu penilaian terhadap lingkungan kerja seperti administrasi data, komunikasi dan sistem terdistribusiyang memiliki perangkat keras (hardware), perangkat lunak (software) dan staf.

\subsection{Information Economics Scorecard}

Pada hasil pemberian bobot nilai dan memberikan nilai proyek yang sudah dijalankan, dapat menghasilkan sebuah skor atau nilai akhir pada proyek. Nilai tersebut akan dapat digunakan bila proyek yang sudah dianalisis lebih dari suatu kebutuhan sehingga dapat digunakan sebagai pedoman dalam melakukan penilaian sebuah proposal proyek teknologi informasi. Karena proyek saat ini yang dibahas merupakan sebuah proyek tunggal, sehingga yang dapat lebih ditekankan adalah pada nilai dari ROI, yang merupakan penilaian tentang sejauh mana manfaat-manfaat proyek yang dijalankan, khususnya pada proyek yang nilainya sulit untuk terukur (intangible), dapat memberikan sebuah kontribusi pada pengembalian investasi teknologi informasi. Pembobotan pada Information Economics scorecard dapat diasumsikan atau diperkirakan jumlahnya seperti dapat dilihat pada Tabel 3 dengan acuan hasil predikat pada Tabel 4.

Tabel 3. Information Economics Scorecard [5]

\begin{tabular}{lccccccccccc}
\hline \multicolumn{1}{c}{ Evaluator } & \multicolumn{1}{c}{ Domain Bisnis } & \multicolumn{7}{c}{ Domain Teknologi } & Skor \\
\hline Faktor & $\mathrm{ROi}^{*}$ & $\mathrm{SM}^{*}$ & $\mathrm{CA}^{*}$ & $\mathrm{MI}^{*}$ & $\mathrm{CR}^{*}$ & $\mathrm{OR}^{*}$ & $\mathrm{SA}^{*}$ & $\mathrm{DU}^{*}$ & $\mathrm{TU}^{*}$ & $\mathrm{IR}^{*}$ & \\
Domain Bisnis & +2 & +2 & +2 & +3 & +5 & +2 & +8 & -4 & -4 & +3 & \\
Domain Teknologi & 2 & 1 & 1 & 3 & 3 & 3 & & & & & \\
Total Skor & & & & & & & 2 & 2 & 2.5 & 2 & \\
\hline
\end{tabular}

Tabel 4. Predikat Skor Akhir IE Scorecard

\begin{tabular}{cc}
\hline Skor Yang Dicapai & Predikat \\
\hline $71-100$ & Sangat Baik \\
$41-70$ & Baik \\
$11-40$ & Cukup \\
$(-21)-10$ & Kurang \\
$(-50)-(-20)$ & Sangat Kurang \\
\hline
\end{tabular}

\section{KESIMPULAN}

Berdasarkan pada hasil analisis yang telah dilakukan, maka dapat disimpulkan bahwa penerapan teknologi informasi Augmented Reality Technology pada Museum Sangiran sangat membantu manajemen pengelola dalam melakukan promosi dan pemberian informasi serta bahan pembelajaran bagi pengunjung dan masyarakat luas yang sudah sesuai dengan rancangan strategis jangka panjang dan SOTK dari pengelola Museum Sangiran. Perhitungan pada nilai ROI untuk mengetahui manfaat investasi teknologi informasi pada Museum Sangiran yang didasarkan pada perhitungan traditional cost benefit analysis dan perhitungan nilai ROI yang berdasarkan pada penilaian Value Linking, Value Acceleration, dan Value Restructuring. Pada nilai ROI terjadi penambahan nilai manfaat dan juga penambahan pada nilai Value Linking sebesar $138 \%$, Value Acceleration sebesar $72 \%$ serta peningkatan penilaian pada Value Restructuring sebesar $204 \%$. Setelah dilakukan pengukuran dampak ekonomis menggunakan Information Economics scorecard dapat diketahui bahwa pada tingkat faktor bisnis domain dan faktor teknologi domain pada Museum Sangiran didapatkan hasil dengan predikat cukup. Hal tersebut memberikan tanda bahwa nilai investasi terhadap penerapan teknologi informasi ART pada Museum Sangiran memiliki nilai resiko yang cukup kecil sehingga mudah dikembangkan.

Metode Information Economics dapat digunakan untuk membantu suatu perusahaan atau instansi untuk mengukur dan membuat prioritas proyek berdasarkan nilai kembali dari investasi. Metode Information Economicsjuga dapat difungsikan untuk membuat perbandingan antara beberapa proyek teknologi informasi dengan tujuan untuk dapat menetukan sebuah skala prioritas pada pengembangan teknologi informasi, sebab metode Information Economicsakan menghasilkan hasil akhir berupa skor yang dapat memberikan nilai rekomendasi pada manajemen pengelolaan. Dalam perkembangan kedepannya, penerapan metode Indormation Economics dapat diijadikan sebagai acuan untuk memberikan kontribusi pada penelitian selanjutnya karena bila dapat membanding dua buah teknologi informasi yang berbeda tipe akan sangat membantu dalam menentukan arah investasi teknologi informasi tersebut. 


\section{DAFTAR PUSTAKA}

[1] Nugroho, Fendy P. 2017. Implementasi Augmented Reality Technology (ART) Sebagai Media Promosi Tentang Museum Purbakala Sangiran Kabupaten Sragen. Yogyakarta: Universitas Amikom Yogyakarta.

[2] Mustaqim I., Kurniawan N. 2017. Pengembangan Media Pembelajaran Berbasis Augmented Reality. Jurnal Edukasi Elektro, Vol. 1, No. 1.

[3] Dekleva, Sasha. 2005. Justifying Investment in IT. Journal of information Technology Management Volume XVI, Number 3 2005. Depaul University.

[4] Hertingkir F., Wardani D. 2017. Analisis Kelayakan Anggaran Investasi Teknologi Informasi dengan Analisis Cost Benefit. Jurnal Keuangan dan Perbankan, Vol 14 No. 1. ISSN: 1829-9865.

[5] Tjahjono B. 2011. Penerapan Information Economics Sistem Aplikasi Billing dan Penggajian Karyawan Pada PT. MC NET, Konferensi Nasional Sistem dan Informatika, KNS\&III-066 Hal 418-421.

[6] Zulkifli. 2016. Implementasi Metode Information Economics (IE) Untuk Menganalisis Manfaat Investasi Sistem Dan Teknologi Informasi USNI. Jurnal Satya Informatika Vol. 1 No. 2 Hal. 65-81.

[7] Mulyantari E. 2016. Strategi pengembangan Situs Manusia Purba Sangiran Sragen Sebagai Daya Tarik Wisata Budaya. Jurnal Media Wisata, Volume 14 Nomor 1 Hal. 333-344.

[8] Purnomo FA., Santoso PI., dkk. 2017. Implementation of Augmented Reality Technology in Sangiran Museum with Vuforia. International Conference on Advanced Materials for Better Future. doi:10.1088/1757899X/333/1/012103.

[9] Santoso, L. W. 2014. Analisis Investasi Sistem Informasi dengan Menggunakan Domain Teknologi-Metode Information Economics. Jurnal Universitas Kristen Petra.

[10] Sibarani, A. J. 2014. Analisis Sistem Informasi Rumah Sakit Menggunakan Metode Information Economics. Jurnal Informatika Vol. 8, No. 2. 